\title{
HUBUNGAN MINAT BELAJAR DAN HASIL BELAJAR MATEMATIKA SISWA KELAS V SDN SE KECAMATAN KUTOARJO TAHUN AJARAN 2019/2020
}

\author{
Hanaan Rofiiqoh ${ }^{1}$, Tri Saptuti.S ${ }^{2}$, Ratna Hidayah ${ }^{3}$ \\ Sebelas Maret University \\ hanaanrofiiqoh18@gmail.com
}

\section{Article History \\ accepted 01/10/2020}

approved 01/11/2020

\begin{abstract}
The study aimed to prove positive correlation between interest in learning and mathematics learning outcomes to fifth grade students of public elementary schools in Kutoarjo sub-district in academic year of 2019/2020 and to determine the contribution of interest in learning to mathematics learning outcomes to fifth grade students of public elementary schools in Kutoarjo sub-district in academic year of 2019/2020. The research was quantitative correlational study. Sampling method was cluster random sampling technique with application of the Statistical Product and Service Solution (SPSS) version 16. The samples were 300 fifth grade students in thirteen public elementary schools in Kutoarjo sub-district. Data collection techniques were questionnaires and test. Data analysis used correlation test of Pearson product moment with a significance level of 0.05 and adjusted $R$ square. The correlation test showed Sig. $=0.000$ (sig. $<0.05$ ) with the coefficient between interest in learning and learning outcomes of mathematics is 0,459 . Based on the research result it can be concluded that the correlation is moderate and that there was positive and significant correlation between interest in learning and mathematics learning outcomes. It indicated that the higher interest in learning, the higher mathematics learning outcomes to fifth grade students of public elementary schools in Kutoarjo sub-district in academic year of 2019/2020 Interest in learning contributed $20.91 \%$ to mathematics learning outcomes. The amount of contibution to mathematics learning outcomes is $20,91 \%$
\end{abstract}

Keywords: interest in learning, mathematics learning outcomes.

Abstrak: Penelitian ini bertujuan untuk membuktikan adanya korelasi positif antara minat belajar siswa dengan hasil belajar matematika siswa kelas V SDN se-Kecamatan Kutoarjo tahun ajaran 2019/2020 dan mengetahui besarnya sumbangan minat belajar terhadap hasil belajar matematika siswa kelas V SDN se-Kecamatan Kutoarjo tahun ajaran 2019/2020. Penelitian ini merupakan penelitian kuantitatif dengan metode korelasi. Pengambilan sampel dilakukan dengan teknik cluster random sampling dengan bantuan aplikasi Statistical Product and Serice Solution (SPSS) versi 16. Jumlah sampel dalam penelitian ini yaitu 300 siswa di tigabelas SDN seKecamatan Kutoarjo. Pengambilan data menggunakan angket dan tes. Analisis data menggunakan uji korelasi pearson product moment dengan taraf signifikansi 0,05 dan menggunakan sumbangan efektif.Pada pengujian korelasi didapatkan sig $=0,000(\mathrm{sig}<0,05)$ dengan hasil koefisien korelasi antara minat belajar dan hasil belajar matematika yaitu 0,459. Berdasarkan hasil penelitian ini dapat disimpulkan bahwa korelasi sedang dan terdapat hubungan positif dan signifikan antara minat belajar dan hasil belajar matematika yang menunjukkan semakin tinggi minat belajar siswa, maka akan semakin tinggi pula hasil belajar matematika siswa kelas V SDN se-Kecamatan Kutoarjo Tahun Ajaran 2019/2020. Besarnya sumbangan minat belajar terhadap hasil belajar matematika yaitu $20,91 \%$.

Kata kunci: minat belajar, hasil belajar matematika 


\section{PENDAHULUAN}

Matematika menjadi salah satu mata pelajaran penting yang diajarkan dari jenjang sekolah dasar hingga perguruan tinggi berfungsi mengembangkan kemampuan berpikir dalam memecahkan suatu permasalahan. Perkembangan ilmu pengetahuan dan perkembangan kebudayaan manusia tidak pernah lepas dari matematika karena merupakan ilmu penting yang tidak hanya membekali siswa dalam kemampuan menggunakan perhitungan atau rumus tetapi juga digunakan di kehidupan sehari-hari. Namun, matematika dengan materi yang berhubungan dengan rumus-rumus abstrak masih dipandang sebagai salah satu mata pelajaran yang tidak disenangi atau bahkan dibenci pada kebanyakan siswa yang mempelajarinya sehingga beberapa siswa mengalami kesulitan dalam mengerjakan soal matematika yang diberikan oleh guru berakibatkan hasil belajar siswa kurang maksimal.

Hasil belajar matematika menjadi tolok ukur keberhasilan suatu proses pembelajaran. Dengan adanya hasil belajar, guru dapat mengetahui ketercapaian kompetensi yang telah dikuasai oleh siswa. Menurut Daud (2012: 250) hasil belajar matematika merupakan salah satu indikator kualitas dari pengetahuan yang dikuasai oleh siswa setelah mengikuti proses belajar mengajar dalam waktu tertentu dilihat dari tinggi rendahnya hasil belajar yang diperoleh siswa. Keberhasilan belajar siswa menjadi penentu ketercapaian tujuan belajar yang telah ditetapkan. Namun, untuk mencapai hasil belajar siswa yang maksimal dalam mata pelajaran matematika masih mengalami kesulitan.

Menurut Ekawati (2014: 2) hasil belajar adalah akibat dari proses belajar yang dialami siswa setelah melakukan penilaian berupa angka untuk melambangkan kemampuan dan keberhasilan siswa. Namun apabila hasil yang diperoleh siswa masih rendah maka guru berusaha mengetahui penyebabnya agar nilai siswa menjadi lebih baik. Menurut Hamdan \& Khader (2015: 130) berpendapat bahwa hasil belajar sebagai dasar untuk mengukur dan melaporkan prestasi akademik siswa serta kunci dalam mengembangkan desain pembelajaran selanjutnya agar lebih efektif sehingga muncul keselarasan antara yang dipelajari siswa dengan bagaimana siswa dinilai. Menurut Susanto (Haryati, 2015: 10) berpendapat bahwa matematika ialah salah satu ilmu yang dapat meningkatkan kemampuan berpikir, berargumentasi, memberi kontribusi dalam penyelesaian masalah sehari-hari dan dalam dunia kerja, serta memberi dukungan terhadap pengembangan ilmu pengetahuan dan teknologi. Suhendri (2011: 32) berpendapat bahwa matematika ialah ilmu tentang bilangan, bangun, keterhubungan konsep dan logika dengan lambang atau simbol untuk menyelesaikan permasalahanpermasalahan di kehidupan sehari-hari.

Berdasarkan pendapat di atas, dapat disimpulkan bahwa hasil belajar matematika ialah pengukur kemampuan untuk melihat ketercapaian prestasi siswa selama mengikuti pembelajaran tentang bilangan, bangun, keterhubungan konsep dan logika untuk meningkatkan kemampuan dalam memecahkan permasalahan dari aspek kognitif, afektif dan psikomotor berupa angka untuk melambang ketercapaiannya.

Menurut Majid (Nurhasanah \& Sobandi, 2016: 130) hasil belajar siswa dipengaruhi oleh dua faktor yaitu faktor internal meliputi gangguan kesehatan, cacat tubuh, faktor psikologis (intelegensi, minat belajar, perhatian, bakat, motivasi, kematangan dan kesiapan peserta didik), dan faktor kelelahan. Sedangkan faktor eksternal meliputi faktor keluarga, sekolah, dan masyarakat. Salah satu faktor internal yang mempengaruhi hasil belajar ialah minat belajar (Suwardi, 2012: 2). Siswa yang memiliki minat dalam pembelajaran tertentu maka ia akan berusaha menguasai pembelajaran yang diminati tersebut. Peran guru sangat penting untuk menumbuhkan minat dan keberhasilan dalam belajar siswa. Minat belajar siswa memiliki pengaruh besar pada proses belajar matematika dilihat saat mempelajari materi, siswa tidak mempunyai rasa keinginan yang besar untuk memahami bahkan mendalaminya maka siswa memiliki hasil kurang maksimal (Tambunan, 2016: 208). 
Minat belajar dan hasil belajar matematika memiliki hubungan. Haryati (2015) dalam penelitiannya menyatakan bahwa terdapat hubungan antara minat belajar dengan prestasi belajar matematika siswa kelas V SDN gugus Wonokerto Turi Sleman dengan nilai korelasi positif yaitu 0,565 yang termasuk dalam tingkat hubungan sedang.

Hal tersebut berarti semakin tinggi minat belajar siswa, maka akan semakin tinggi pula hasil belajar matematika siswa. Begitu pun sebaliknya, semakin rendah minat belajar siswa, maka akan semakin rendah pula hasil belajar matematika siswa.

Berdasarkan penjelasan di atas, pemasalahan dalam penelitian ini adalah : (1) Apakah minat belajar siswa berkorelasi positif dengan hasil belajar matematika siswa SDN se-Kecamatan Kutoarjo tahun ajaran 2019/2020 ?; (2) Seberapa besar sumbangan minat belajar siswa terhadap hasil belajar siswa matematika SDN se-Kecamatan Kutoarjo tahun ajaran 2019/2020 ?.

Berdasarkan permasalahan di atas maka tujuan dari penelitian ini yaitu : (1) Membuktikan adanya korelasi positif antara minat belajar siswa dengan hasil belajar matematika siswa kelas V SDN se-Kecamatan Kutoarjo tahun ajaran 2019/2020; (2) menentukan besarnya sumbangan minat belajar terhadap hasil belajar matematika siswa kelas V SDN se-Kecamatan Kutoarjo tahun ajaran 2019/2020.

\section{METODE}

Desain penelitian yang digunakan yaitu penelitian kuantitatif dengan metode penelitian korelasi. Purwanto (2010: 177) menyatakan bahwa penelitian korelasi adalah penelitian yang melibatkan hubungan satu atau lebih variabel dengan satu atau lebih variabel lain pada satu kelompok.

Populasi pada penelitian ini yaitu semua siswa kelas V SDN di Kecamatan Kutoarjo dengan jumlah 39 sekolah dasar. Pengambilan sampel dilakukan dengan teknik probability sampling jenis cluster random sampling. Jumlah sampel dalam penelitian ini yaitu 300 siswa di tigabelas SDN di Kecamatan Kutoarjo. Pengambilan sampel dilakukan secara random menggunakan aplikasi SPSS versi 16.

Ada beberapa cara yang dapat dilakukan dalam mengumpulkan data penelitian. Teknik pengumpulan data terdapat lima macam yaitu observasi, angket, wawancara, tes, dan dokumentasi (Yoni, 2010: 172-173). Teknik pengumpulan data yang digunakan dalam penelitian ini yaitu angket dan ujian (tes). Angket digunakan untuk mengumpulkan data penelitian pada variabel bebas yaitu minat belajar, sedangkan ujian (tes) digunakan untuk mengumpulkan data penelitian pada variabel terikat yaitu hasil belajar. Sebelum digunakan untuk penelitian, angket dan tes diuji validitas dan reliabilitasmya terlebih dahulu di dua SDN di Kecamatan Kutoarjo.

Uji prasyarat data yang digunakan adalah uji normalitas menggunakan uji liliefors dan uji linieritas. Uji hipotesis yang digunakan adalah uji korelasi sederhana yang digunakan untuk menguji ada atau tidaknya hubungan antara minat belajar dengan hasil belajar dan sumbangan efektif yang digunakan untuk mencari besarnya sumbangan variabel minat belajar terhadap variabel hasil belajar.

\section{HASIL DAN PEMBAHASAN}

Penelitian ini bertujuan untuk mendeskripsikan korelasi antara minat belajar dan hasil belajar matematika siswa kelas V SDN se-Kecamatan Kutoarjo. Jumlah sampel dalam penelitian ini ialah sebanyak 300 orang dari 13 SD se-Kecamatan Kutoarjo. Dari sampel tersebut diperoleh data hasil pengisian angket minat belajar hasil belajar matematika siswa yang telah didistribusikan ke dalam tabel distribusi hingga dapat diolah menggunakan perhitungan statistik dan kemudian dihitung nilai koefisien korelasi product moment $(r)$. Hasil uji normalitas sebaran terhadap variabel minat belajar menghasilkan nilai sig $=0,071$ ( $\mathrm{sig}>0,05)$. Hasil uji berdasarkan kaidah menunjukkan variabel minat belajar adalah normal. Hasil uji normalitas sebaran terhadap variabel hasil belajar matematika menghasilkan nilai sig $=0,071$ ( $\mathrm{sig}>0,05)$. Hasil uji berdasarkan 
kaidah menunjukkan variabel hasil belajar matematika adalah normal. Hasil uji linieritas antara minat belajar dengan hasil belajar matematika memiliki sig $=0,307$ ( $\operatorname{sig}>0,05)$ yang berarti hubungannya dinyatakan linier. Adapun hasil perhitungan korelasi dari data angket minat belajar dan hasil belajar matematika siswa yang telah diolah dapat dilihat pada table berikut.

Tabel 1. Hasil Analisis Korelasi Minat Belajar dan Hasil Belajar Matematika

\begin{tabular}{|c|c|c|c|}
\hline \multicolumn{4}{|c|}{ Correlations } \\
\hline & & \multicolumn{2}{|c|}{ hasil belajar matematika minat belajar } \\
\hline hasil belajar & Pearson & 1 & $459^{* *}$ \\
\hline \multirow[t]{3}{*}{ matematika } & Correlation & & \\
\hline & Sig. (1-tailed) & &, 000 \\
\hline & $\mathrm{N}$ & 300 & 300 \\
\hline \multirow[t]{3}{*}{ lat belajar } & $\begin{array}{l}\text { Pearson } \\
\text { Correlation }\end{array}$ & $459^{* *}$ & 1 \\
\hline & Sig. (1-tailed) & 000 & \\
\hline & $\mathrm{N}$ & 300 & 300 \\
\hline
\end{tabular}

Berdasarkan hasil analisis dengan menggunakan uji korelasi pearson product moment, diketahui bahwa terdapat hubungan positif dan signifikan antara minat belajar dan hasil belajar matematika dengan hasil $r=0,459$, dan sig $=0,000$ ( $\operatorname{sig}<0,000$ ). Sesuai dengan hasil dari uji korelasi tersebut maka hipotesis yang menyatakan ada korelasi positif dan signifikan antara minat belajar dan hasil belajar matematika siswa kelas V SDN se-Kecamatan Kutoarjo tahun ajaran 2019/2020 dapat diterima dan dalam kategori sedang. Berdasarkan hasil penelitian tersebut dapat disimpulkan bahwa semakin tinggi minat belajar siswa, maka akan semakin tinggi pula hasil belajar matematika siswa. Begitupun sebaliknya, semakin rendah minat belajar siswa, maka akan semakin rendah pula hasil belajar matematika siswa.

Diterimanya hipotesis ini sesuai dengan penelitian yang dilakukan oleh Haryati (2015: 8) yang menyatakan bahwa terdapat hubungan antara minat belajar dengan prestasi belajar matematika siswa kelas V SDN gugus Wonokerto Turi Sleman dengan nilai korelasi positif yaitu 0,565 yang termasuk dalam kategori sedang. Tingkat prestasi belajar matematika siswa kelas $\mathrm{V}$ berada pada kategori tinggi frekuensinya sebesar 22 siswa dengan persentase 19,64\%, pada kategori sedang frekuensinya sebesar 76 siswa dengan persentase $67,86 \%$, dan pada kategori rendah frekuensinya sebesar 14 siswa dengan persentase $12,5 \%$. Hal ini menunjukkan prestasi belajar matematika siswa kelas V SD se-Gugus Wonokerto berada pada kategori sedang. Hal ini mendukung hubungan anatara variabel minat belajar dengan prestasi belajar matematika positif. Orang belajar dapat mengalami kesulitan. Pada penelitian Arisetiawan (Haryati, 2015) faktor yang memiliki kontribusi terbesar terhadap kesulitan belajar siswa adalah minat belajar, kebiasaan belajar, dan didikan orang tua yang memiliki kontribusi sebesar $25,792 \%$. Angka ini merupakan angka terbesar, sementara sisanya dipengaruhi oleh enam faktor yang lain yaitu faktor jasmaniah, psikologis, kelelahan, keluarga, sekolah dan masyarakat.

Sesuai dengan hasil perhitungan sumbangan minat belajar terhadap hasil belajar matematika, didapatkan hasil yang menyatakan bahwa minat belajar dapat meningkatkan hasil belajar matematika sebesar 20,91\% dan sisanya sebesar 79,09 \% dipengaruhi oleh faktor-faktor lain seperti kesehatan jasmani dan rohani, bakat, intelegensi, bakat, motivasi serta lingkungan sekitar.

Berdasarkan uraian di atas, dapat disimpulkan bahwa hasil penelitian ini telah sesuai dengan teori yang ada dan didukung pula dengan penelitian yang relevan, maka 
Volume 8 Nomor 3 Tahun 2020

hasil penelitian ini adalah korelasi positif dan signifikan antara minat belajar dengan hasil belajar matematika siswa kelas V SDN se-Kecamatan Kutoarjo tahun ajaran 2019/2020.

\section{SIMPULAN}

Berdasarkan hasil penelitian dan pembahasan, didapatkan kesimpulan bahwa 1. Terdapat hubungan yang positif dan signifikan antara minat belajar dengan hasil belajar matematika siswa kelas $\mathrm{V}$ SDN se-Kecamatan Kutoarjo dengan tingkat korelasi sedang yaitu 0,459. Artinya, semakin tinggi minat belajar maka akan semakin tinggi pula hasil belajar matematika siswa.

2. Sumbangan variabel minat belajar terhadap hasil belajar matematika yaitu $20,91 \%$ sedangkan sisanya dipengaruhi oleh faktor-faktor lain seperti kesehatan jasmani dan rohani, bakat, intelegensi, bakat, motivasi serta lingkungan sekitar.

Penerapan minat belajar dapat dilakukan dengan berbagai cara seperti memberikan kesempatan kepada siswa untuk mengambil keputusan, ciptakan suasana lingkungan kelas yang nyaman serta bervariasi, ciptakan kompetisi antar siswa yang positif, tawarkan hadiah, berikan tanggung jawab kepada siswa, berikan kesempatan kepada siswa untuk belajar secara berkelompok, dorong mereka untuk merefleksikan diri, mengenal dan mengetahui minat siswa, bantu siswa untuk menemukan motivasi dari dalam dirinya, kelola kecemasan siswa agar dapat diminimalisir, buatlah tujuan yang tinggi tetapi masih bisa dicapai, dan berikan feedback dan bantu menemukan solusi. Upaya peningkatan minat belajar juga perlu didukung oleh sarana dan prasarana seperti pengadaan buku-buku yang berkaitan dengan matematika, menyiapkan soal-soal latihan di kelas, dan pengadaan alat peraga. Melalui upaya-upaya di atas diharapkan dapat meningkatkan minat belajar seperti sikap percaya diri, tanggung jawab, mampu bekerja sendiri, mampu mengambil keputusan, dan memiliki hasrat bersaing untuk maju sehingga minat belajar siswa dapat meningkat, sehingga diharapkan hasil belajar dapat meningkat.

\section{DAFTAR PUSTAKA}

Daud, F. (2012). Pengaruh Kecerdasan Emosional (EQ) dan Motivasi Belajar terhadap Hasil Belajar Biologi Siswa SMA 3 Negeri Kota Palopo. Jurnal Pendidikan dan Pembelajaran (JPP), 19(2), 243-255.

Ekawati, A. (2014). Pengaruh Motivasi dan Minat terhadap Hasil Belajar Matematika Kelas VII di SMPN 13 Banjarmasin. LENTERA Jurnal Ilmiah Kependidikan, 9(2), 1-10.

Hamdan, A.T., \& Khader, F. (2015). Alignment of Intended Learning Outcomes with Quellmalz Taxonomy and Assessment Practices in Early Childhood Education Courses. Journal of Education and Practice, 5(3), 130-137.

Haryati, N. (2015). Hubungan Minat Belajar dengan Prestasi Belajar Matematika Siswa Kelas V SD Se-Gugus Wonokerto Turi Sleman Tahun Ajaran 2014/2015. Jurnal Pendidikan Guru Sekolah Dasar, 4(13).

Nurhasanah, S., \& Sobandi, A. (2016). Minat belajar sebagai determinan hasil belajar siswa. Jurnal Pendidikan Manajemen Perkantoran (JPManper), 1(1), 128-135.

Purwanto. (2012). Metode Penelitian Kuantitatif untuk Psikologi dan Pendidikan. Yogyakarta: Pustaka Pelajar.

Suhendri, H. (2011). Pengaruh Kecerdasan Matematis-Logis dan Kemandirian Belajar terhadap Hasil Belajar Matematika. Formatif: Jurnal IImiah Pendidikan MIPA, 1(1), 29-39.

Suwardi, D. R. (2012). Faktor-Faktor yang Mempengaruhi Hasil Belajar Siswa Kompetensi Dasar Ayat Jurnal Penyesuaian Mata Pelajaran Akuntansi Kelas XI IPS di SMA Negeri 1 Bae Kudus. Economic Education Analysis Journal, 1(2), 1-7. 
Volume 8 Nomor 3 Tahun 2020

Tambunan, N. (2016). Pengaruh Strategi Pembelajaran dan Minat Belajar terhadap Kemampuan Berpikir Kreatif Matematis Siswa. Formatif: Jurnal IImiah Pendidikan MIPA, 6(3), 207-219.

Yoni, A. dkk. (2010). Menyusun Penelitian Tindakan Kelas. Yogyakarta: Familia. 